\title{
Innovative ways of implementing municipal programs in the housing and utilities sector and urban environment
}

\author{
Inna Zilberova ${ }^{1, *}$, and Vadim Mailyan ${ }^{2}$ \\ ${ }^{1}$ Don State Technical University, Rostov-on-Don, Russia \\ ${ }^{2}$ Rostov-on-Don College of Civil Engineering, Rostov-on-Don, Russia
}

\begin{abstract}
The paper includes the consideration of existing methods for implementing urban programs in the housing and utilities sector and the urban environment; as a result of the analysis, it was found that they are unsystematic by nature, do not have criteria for evaluating the effectiveness and even the minimum parameters of the required works. In this regard, the paper defines innovative ways of implementing municipal programs in the housing and utilities sector and the urban environment, which take into account the peculiarities of the municipal programs implementation. The method proposed in the paper is based on an innovative approach to determining the targets for ensuring the preservation of the housing stock and improving the quality and comfort of the urban environment in the municipal formation territory. As the main tool, the method of the prospect planning and the selection of functional strategies has been used. In the paper, approaches to the development of innovative methods for planning urban programs in the housing and utilities sector and the urban environment are formed; the selection criteria for the taken organizational and technological decisions of the repair and construction industry in the housing and utilities sector and the urban environment are determined; possible combinations of mastering the types of work for synchronizing the processes of yard landscaping and the overhaul of apartment buildings are established.
\end{abstract}

\section{Introduction}

Construction as an industry occupies one of the leading places in the industrial complex of the Russian Federation and makes a huge contribution to the development of all sectors of the national economy [1]. Construction is one of the key capital-forming industries, on which the formation of the national economy largely depends [2].

This industry combines two types of activities in general:

- construction activities - the real estate construction and repair (the direct scope of application of construction organizations' capacities);

* Corresponding author: zilberova2011@yandex.ru 
- housing and utility services - ensuring the effective functioning and operation of housing facilities and the urban environment, including utilities (water, heat and gas, ventilation, drainage, electricity, elevators, etc.).

Construction and housing and utility services, as a branch of the national economy, includes the full cycle of creation and functioning of real estate facilities (buildings and structures) and all related activities.

Today, the construction industry in Russia is going through one of the most difficult periods in its history. After a record volume of housing commissioning, a recession began, which amounted to more than 6\% in 2018, and continued in 2019.

The positive dynamics of investments and commissioning in 2019 compared to 2018 is observed due to the construction and modernization of buildings and structures for the agricultural sector and repair work in the housing and utility sector and urban environment.

The addition of the Housing Code of Russia with a chapter on the organization of a complete overhaul system (hereinafter referred to as $\mathrm{CO}$ ) of common property in apartment buildings (hereinafter referred to as $\mathrm{AB}$ ) has become one of the main factors in the growth of repair and construction volumes. The overhaul today is the most ambitious housing renovation project in the history of the country.

The increase in the volume of repair and construction works (hereinafter - RCW) is also due to the implementation of the prioritized national project "Housing and Urban Environment". In November 2016, the Ministry of Construction of the Russian Federation approved the identification summary of the federal project "Formation of a comfortable urban environment" in order to improve the quality and comfort of the urban environment in the territory of municipal formations.

As part of the project, landscaping of yards and common spaces is being carried out. The declared amount of financing for the improvement of common yard territories is 41.538 billion rubles, and the one for the improvement of parks in small towns - 663 million rubles.

It is necessary to take into account that the considered projects are of a long-term nature, for example, the overhaul programs are aimed for 35 years (2014 -2049), and the "Formation of a comfortable urban environment" is intended for 6 years (2018-2024).

Thus, we can conclude that the RCW market is promising and quite attractive for business [3]. The attractiveness indicators of this market are due to a set of various factors. The main ones are: size, growth opportunities and its social role.

The social significance of projects implemented on the RCW market requires a particular consideration. The implementation of the repair and construction work programs (hereinafter - RCWP) in the housing and utilities sector and the urban environment is aimed at creating favorable living conditions for citizens of the Russian Federation and ensuring the sustainable functioning of regional programs ensuring the timely implementation of activities, the required quality and reasonable cost of works (services) $[4,5]$.

At the same time, there are no clear requirements for organizing the modern RCWP in the housing and utilities sector and in the urban environment, including those involving not only the participants in the production process, but also the owners, as well as methods for their achievement in Russia. Existing city programs in the housing and utilities sector and the urban environment are unsystematic in nature, do not have criteria for evaluating the effectiveness and even the minimum parameters of the required works [6,7]. In this regard, it is necessary:

- to study the features of planning and implementing urban programs in the housing and utilities sector and in the urban environment;

- to formulate approaches to the development of innovative methods for planning urban programs in the housing and utilities sector and in the urban environment; 
- to determine the criteria for the selection of organizational and technological decisions of repair and construction works in the housing and utilities sector and in the urban environment.

\section{Materials and Methods}

The implementation of municipal programs in the housing and utilities sector and in the urban environment is currently one of the most discussed issues among socially significant ones [8-10].

Changes in housing legislation introduced new rules for organizing complete overhaul programs for apartment buildings. The start of the federal project "Formation of a comfortable urban environment" defined new requirements for the organization of work on the improvement of common spaces and yard territories (hereinafter - ICSYT). In this regard, issues of the implementation of the CO and ICSYT programs with mandatory guarantees for the efficient distribution of funds during their planning have become urgent.

The need for an innovative and strategic approach to determining targets for ensuring the preservation of the housing stock and improving the quality and comfort of the urban environment in the municipal formation territory determines the development and use of long-term planning methods and the selection of functional strategies [11, 12].

The functional strategy for ensuring the preservation of the housing stock and improving the quality and comfort of the urban environment in the municipal formation territory is the scientifically based synchronization of work that is being carried out both within the framework of the project of formation of a comfortable urban environment and as part of $\mathrm{AB} \mathrm{CO}$.

The synchronization of landscaping works in yard territories (hereinafter - YT), which are being carried out both within the framework of the project for the formation of a comfortable urban environment and the work carried out as part of AB CO, is a fundamentally important task. Improvement of a number of important technical and economic indicators and achievement of specified indicators of efficiency and performance of the city programs under consideration is possible only when carrying out work synchronization activities.

The features of synchronization of city programs are determined by the conditions for combining the main processes; in the most general case, such processes can be performed in a different order, in different directions, at different times and in fields of operations. In order to describe and evaluate technical and organizational and technological solutions, it is necessary to determine indicators characterizing options for the sequence of development of types of work, the development direction and the work duration [13].

The synchronization of the AB CO and ICSYT programs will allow creating a comprehensive construction stream, which is a group of organizationally related object and specialized flows, united by common products in the form of a renovated $\mathrm{AB}$ with a landscaped YT [14].

An analysis of the regulatory legal acts of the Russian Federation in the field of construction, housing and utility services and improvement indicates the current use of the two terms: "yard territory" and "outdoor space".

Based on the foregoing, it would be wrong to assume that the outdoor space and the yard territory are identical terms or names of the same facility.

In order to avoid legal and logical contradictions, two options are considered in the paper (Figure 1):

1. The boundaries of the outdoor space and the yard territory coincide - there is one AB is located in the territory 


$$
O S=Y T
$$

where

$O S$ is outdoor space, $Y T$ is yard territory.

2. The outdoor space is a part of the yard territory - there is more than one $A B$

$$
\begin{gathered}
O S_{A B 1}+O S_{A B 2}+\ldots+O S_{A B(n)}=O S \\
O S \neq Y T, \\
O S>Y T \text { or } O S<Y T,
\end{gathered}
$$

where

$O S$ is outdoor space, $Y T$ is yard territory, $A B n$ - apartment building number limiting the space of the yard territory.

It is accepted in the paper that $\mathrm{OS}=\mathrm{YT}$, the option $\mathrm{OS} \neq \mathrm{YT}$ is not considered in the paper based on the condition that this is characterized by legal conflicts, the presence of which is a limitation of inclusion in the program of YT improvement. The application in other cases is possible by the principle of analogy.

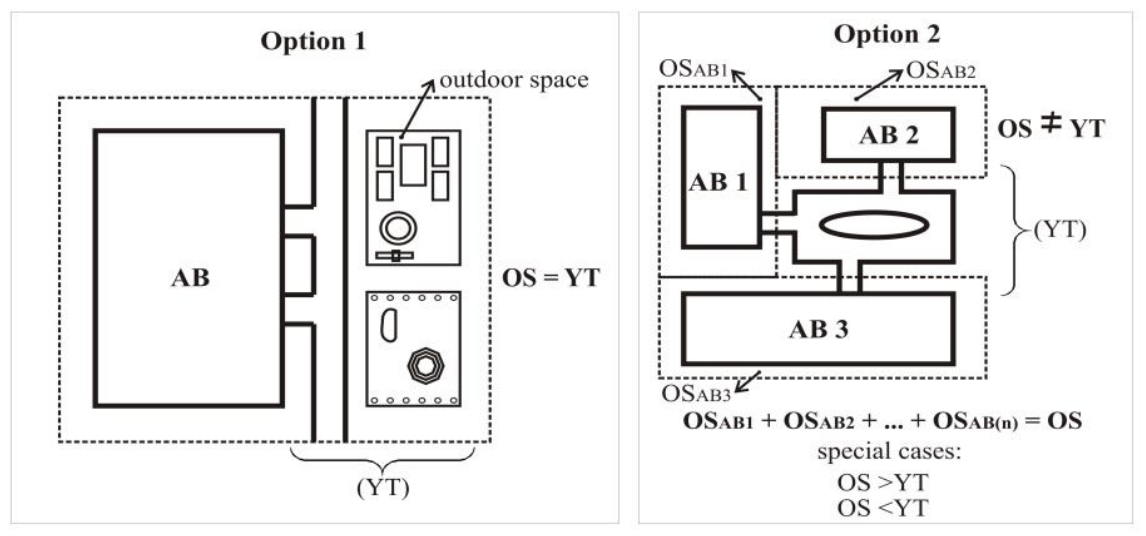

Fig. 1. Options for the location of the outdoor space and yard territory.

The planning of functional strategies is based on the theory of the life cycle of real estate facilities with the consistent implementation of complete overhaul activities. The methodological basis for achieving effective solutions is made up of the methods for the formation of variant models of functional strategies for synchronizing $\mathrm{AB} C \mathrm{CO}$ and $\mathrm{YT}$ improvement at each $\mathrm{AB}$ using organizational and legal restrictions, financial factors and features of its condition, identified on the basis of economic, mathematical and statistical analysis of the above costs.

The selection of functional strategies for synchronizing the $\mathrm{AB} C O$ and $\mathrm{YT}$ improvement is particularly relevant when all the constituent entities of the Russian Federation have adopted long-term regional programs for AB CO and ICSYT.

CO regional programs for the period 2014 - 2040 include a list of all AB located in the territory of the Russian Federation subject (with the exception of unfit buildings and houses being subject to demolition), a list of services (works) for $\mathrm{CO}$ in each $\mathrm{AB}$, as well as the deadline for its implementation established in the regional program. Most of the programs are address lists of houses ordered by actual operating periods with established periods for carrying out $\mathrm{CO}$ and planned lists of repair work. In order to implement the programs, local governments approve short-term plans for implementing the program (up to three years). 
The formed regional and municipal projects for ICSYT for the period of 2019 - 2024 include a list of all YT in need of improvement (taking into account their physical condition) and subject to improvement based on the minimum list of improvement works. The list of YT being included in the annual performance program is formed on the basis of a selection of $\mathrm{AB}$ yard territories by local authorities. The selection of $\mathrm{AB}$ yard territories is carried out by scoring evaluation of the following criteria:

1. Duration of AB operation;

2. Availability of previously conducted $\mathrm{AB} \mathrm{CO}$;

3. Availability of previously conducted $\mathrm{CO}$ of the $\mathrm{AB} Y \mathrm{YT}$;

4. Compliance of the technical condition of the AB YT with the established requirements;

5. Financial discipline of the owners of premises in $\mathrm{AB}$ (amount of the total debt on the payment for the repair and maintenance of housing, CO contributions);

6. Financial participation of owners of premises in terms of the acquisition of elements of improvement;

7. The share of owners (votes of owners of premises) who cast votes for the decision to participate in the AB YT selection, of the total number of votes participating in the meeting.

Under these conditions, local governments (district administrations, housing and utility services departments, etc.), when planning annual production programs for YT improvement, should take into account the timing of the CO implementation defined by the long-term regional program and ensure that all repair activities are synchronized and coordinated in time.

The synchronization of work on YT improvement with the regional program of the housing fund complete overhaul should be based on statistical tools, including the factor analysis, the method of grouping facilities and types of repair activities linked to the system of accumulation of funds of homeowners for $\mathrm{CO}$ and the improvement subvention provided.

At the operational phase of the property life cycle (in this case, we consider AB), a system of models that describe the dynamics of changes in the $A B$ state - physical deterioration, capitalization, energy efficiency of housing and systematization of measures required to improve the quality and comfort of the urban environment, allows the optimization of the planning system of repair work and will ensure the balancing of the $A B$ $\mathrm{CO}$ and YT improvement methods, which guarantees the efficient distribution of financial resources [15].

In the paper, it is further assumed that the synchronization of the $\mathrm{AB} C \mathrm{CO}$ and $\mathrm{YT}$ improvement (hereinafter referred to as synchronization) is the reduction of these processes to the condition when certain stages of different processes take place in a certain order, either with a constant time shift, or simultaneously. The synchronization is meant as ensuring the consistent implementation of the $\mathrm{AB} \mathrm{CO}$ with the establishment of time lags between the deadline set in the regional program and the work on the YT improvement.

In order to ensure the synchronization of city programs, it is necessary to justify the rhythm of repair processes and processes related to improvement, to develop an algorithm for their implementation, as well as to create a system for monitoring compliance with the synchronization of repair and improvement processes, the availability of sufficient resources.

Based on the analysis, it follows that only a change in the direction of the complex of works causes a significant difference in the performance of decisions on synchronization of repair processes and processes related to improvement. When carrying out CO and YT improvement at facilities with dispersed development, there may be not two or not three, but much more options and combinations of directions. The sequence of completing work 
scopes may also be multivariate. The intensity of development of work scopes may vary in different ways.

In order for a variety of options to be considered when choosing a process organization, it is necessary to establish depending on what and how the performance indicators change while synchronizing the YT improvement and $\mathrm{AB} \mathrm{CO}$ processes.

As it was already mentioned, the features of the organization of work during the synchronization of the YT improvement and $\mathrm{AB}$ CO processes are determined by the conditions for the implementation of complex processes; in the most general case, such processes can be performed in a different order, in different directions, at different times and on different sizes of private fields being subject to AB CO or YT improvement. It is proposed to evaluate all these changes in the work by a certain group of indicators and coefficients:

- the number of complex processes (frequent flows);

- the coefficient determining the features of the work scope development in space ( $\left.\tau^{\prime} \mathrm{zi}\right)$;

- the set of elements $\left(\mathrm{n}_{\mathrm{k}}\right)$;

- the volumes of structures in selected areas $\left(\mathrm{V}_{\mathrm{kij}}\right)$;

- the number of private fronts with the largest volume of structures $\left(\mathrm{m}_{\mathrm{o}}\right)$;

- the inequality of the same volumes of structures in private fields $\left(\omega_{0}\right)$;

- the intensity of the types of work $(\rho)$

It is also proposed to include variables that reflect the situation being changed over time:

- duration of individual works $\left(\delta_{\mathrm{t}}\right)_{\mathrm{ij}}$;

- the availability of material resources required for carrying out $t_{\mathrm{ij}}$;

- the availability of financial resources for $\mathrm{F}_{\mathrm{ij}}$;

A change in the sequence of mastering the types of work often leads to an increase or decrease in the duration of work on the $\mathrm{AB} C \mathrm{CO}$ and the YT improvement and the need for replaceable resources [16]. If talking about the importance of the duration of the cycle of work on the $\mathrm{AB} \mathrm{CO}$ and the YT improvement, it turns out that increasing the duration of the cycle leads to a decrease in the economic reliability of investments and, as a consequence, in significant economic and social costs.

The variants of the sequence of development of types of work are associated with the composition and placement of types of work for $\mathrm{AB} \mathrm{CO}$. If $\mathrm{AB} \mathrm{CO}$ is conditionally represented as the set of its elements $n_{k}=n^{\prime}{ }_{k}+n^{\prime \prime}{ }_{k}$, where $n^{\prime}{ }_{k}$ denotes the nomenclature of types of structures according to $\mathrm{AB} \mathrm{CO}$ (facade, roof, foundation), and $n^{\prime \prime}{ }_{k}$ presents types of the required engineering equipment (elevators, electricity, heating, hot and cold water supply).

By analyzing the composition in different types of structures according to $\mathrm{AB} \mathrm{CO}$, it can be verified that in some cases it is not possible to synchronize these works with the works on YT improvement. In this regard, various combinations are possible, which, for the facilities under consideration, are limited to the data indicated in Table 1.

The analysis shows that the organization of the synchronization of processes for the YT improvement and $\mathrm{AB} \mathrm{CO}$ has certain features in each of the combinations. If considering the execution of the types of work of these combinations as a synchronous execution with a constant value of their intensity $\rho_{\mathrm{i}}=$ const, then the duration of works can be obtained. Using Table 1, it is possible to write down all the combinations in the order of mastering the types of works. It should be borne in mind that structures with independent areas can have the reverse order.

In the general case, possible combinations of mastering the types of synchronization processes for the $\mathrm{YT}$ improvement and $\mathrm{AB} \mathrm{CO}$ form the following matrix: 


$$
A=\left[\begin{array}{ccccc}
P_{11}^{0} & \cdot & P_{i 1}^{0} & \cdot & P_{n 1}^{0} \\
P_{12}^{0} & \cdot & P_{i 2}^{0} & \cdot & P_{n 2}^{0} \\
\cdot & \cdot & \cdot & \cdot & \cdot \\
\cdot & \cdot & \cdot & \cdot & \cdot \\
P_{1 j}^{0} & \cdot & \cdot & \cdot & P_{n j}^{0}
\end{array}\right]
$$

here, $\mathrm{j}=1,2 \ldots$ is the combination number. In each row with number $\mathrm{j}$, the value is $\mathrm{P}_{\mathrm{i}}=1$ for processes included in this combination and $\mathrm{P}_{\mathrm{i}}=0$ for combined or missing processes.

Thus, when synchronizing the processes for the YT improvement and $\mathrm{AB} \mathrm{CO}$, there can be many different options $\mathrm{A}\left(\mathrm{P}_{\mathrm{ij}}{ }^{0}\right)$ of the sequence of development of types of work, from which it is necessary to choose the most rational ones for this type of $\mathrm{AB} C \mathrm{CO}$ and improvement as well as the accepted form of financing. Moreover, in order to establish which option is best for this facility being renovated, it is proposed to use a comprehensive evaluation criterion, which simultaneously takes into account the direction of development and the duration of the complex of works on YT improvement and AB CO.

The result will be a transition to a new technical state with elements of innovative improvement, increasing the quality and comfort of the urban environment, as well as the preservation of existing operational indicators of $\mathrm{AB}$ and $\mathrm{YT}$.

\section{Results}

Based on the analysis, it was found that synchronization of work on the YT improvement and $\mathrm{AB} \mathrm{CO}$ is required in all cases, that is, the parallel interaction with the ongoing processes is required. In order to provide this condition, the following should be studied:

- organizational and technological layouts of processes: AB CO and YT improvement;

- existing problems hindering the synchronization.

The results of the conducted analysis will allow developing a unified algorithm for planning urban programs in the housing and utilities sector and in the urban environment.

$\mathrm{V}_{\mathrm{k} 0 \max }, \mathrm{V}_{\mathrm{k} 0}$ are the scopes of work performed during the periods of the highest and lowest rhythm; $\sum \tau_{0}$ are time reserves between the executions of complex processes.

The analysis of organizational and technological schemes showed that the AB CO and the YT improvement works are a group of organizationally related and spatially integrated processes. In order to synchronize the $\mathrm{YT}$ improvement and $\mathrm{AB} \mathrm{CO}$ programs, it is necessary to determine:

- the sequence and timing of works;

- the composition and scope of works, the sequence and duration of their implementation linked to time intervals;

- the need for labor, material and technical resources by type of works;

- the distribution of labor, material and technical resources in time and space;

- the need for materials, products, structures and equipment by temporary periods of work;

- the required capacities of contracting organizations.

In the paper, the main problems were identified that impeded the idea of synchronization of $\mathrm{AB} \mathrm{CO}$ and YT improvement works, which were conditionally divided into groups: 
Table 1. Performance of types of work in various combinations during synchronization of the processes for the yard territories improvement and the complete overhaul of apartment buildings.

\begin{tabular}{|c|c|c|c|c|c|}
\hline No. & $\begin{array}{l}\text { Combinat } \\
\text { ion of } \\
\text { types of } \\
\text { work }\end{array}$ & $\begin{array}{c}\text { Location of } \\
\text { volumes of } \\
\text { the same } \\
\text { denominati } \\
\text { on }\end{array}$ & $\begin{array}{c}\text { Ratio of } \\
\text { volumes of } \\
\text { different } \\
\text { denominations }\end{array}$ & $\begin{array}{l}\text { Duration of the work } \\
\text { scope performance }\end{array}$ & $\begin{array}{l}\text { Type and variety } \\
\text { of work } \\
\text { production } \\
\text { method }\end{array}$ \\
\hline 1 & $n_{k}=$ const & $V_{k i j}=\frac{V_{k j}}{m_{0}}$ & $\frac{V_{k i j}}{V_{k(i=1) i}}=$ const & $\frac{V_{k}}{\rho}+\frac{V_{k 0}}{\rho}\left(n_{k}-1\right)$ & Rhythmic flow \\
\hline 2 & $n_{k}=$ const & $V_{k i j} \neq \frac{V_{k j}}{m_{0}}$ & $\frac{V_{k i j}}{V_{k(i=1) i}}=$ const & $\frac{V_{k}}{\rho}+\frac{V_{k 0 \max }}{\rho}\left(n_{k}-1\right)$ & $\begin{array}{l}\text { Equally variable } \\
\text { rhythmic flow }\end{array}$ \\
\hline 3 & $n_{k}=$ const & $V_{k i j} \neq \frac{V_{k j}}{m_{0}}$ & $\frac{V_{k i j}}{V_{k(i=1) i}} \neq$ const & $\frac{V_{k}}{\rho}+\frac{V_{k 0 \max }}{\rho}\left(n_{k}-1\right)+\sum \tau_{0}$ & $\begin{array}{l}\sum t \text { Variable } \\
\text { rhythmic flows }\end{array}$ \\
\hline 4 & $n_{k} \neq$ const & $V_{k i j}=\frac{V_{k j}}{m_{0}}$ & $\frac{V_{k i j}}{V_{k(i=1) i}}=$ const & $\frac{V_{k}}{\rho}+\frac{V_{k 0}}{\rho}\left(n_{k}-1\right)+\sum \tau$ & $\begin{array}{l}\text { Variable pitch } \\
\text { rhythmic flow }\end{array}$ \\
\hline 5 & $n_{k} \neq$ const & $V_{k i j} \neq \frac{V_{k j}}{m_{0}}$ & $\frac{V_{k i j}}{V_{k(i=1) i}}=$ const & $\frac{V_{k}}{\rho}+\frac{V_{k 0 \max }}{\rho}\left(n_{k}-1\right)+\sum$ & $\begin{array}{l}\text { Equally variable } \\
\tau_{0} \text { rhythmic flow } \\
\text { with a variable } \\
\text { pitch }\end{array}$ \\
\hline 6 & $n_{k} \neq$ const & $V_{k i j} \neq \frac{V_{k j}}{m_{0}}$ & $\frac{V_{k i j}}{V_{k(i=1) i}} \neq$ const & $\frac{V_{k}}{\rho}+\frac{V_{k 0 \max }}{\rho}\left(n_{k}-1\right)+\sum \tau_{0}$ & $+\sum_{\text {rhythmic flows }} t$ Variable \\
\hline
\end{tabular}

- social: The problems are related to the involvement of municipal formations dwellers in the work for creating a comfortable urban environment and landscaping of yard territories. Here it is necessary to develop a mechanism for the interaction of municipalities with dwellers, since at the moment the municipal authorities themselves approve targeted programs while not often taking into account the opinions of citizens;

- managerial: the problems relate to the lack of coordination among all participants in the planning of urban programs in the housing and utility services sector and in the urban environment, including bodies at all levels of government, since not only local governments, but also regional ministries, district administrations and city committees are involved in improvements. Resource organizations often do not coordinate their work too.

- organizational: problems associated with:

- the organization of procurement (competition, auction) and the need to combine the technical specifications of technologically and functionally unrelated services, which may lead to limited competition in the procurement process and a reduction in the number of bidders;

- the absence of estimated indicators and coefficients that take into account different options when choosing methods for organizing processes of AB CO and YT improvement;

- technological (production):

- insufficient number of qualified teams of permanent composition, where the technology for the production of $\mathrm{AB} \mathrm{CO}$ and YT improvement has been developed and the 
supply is organized on logistic principles, with the constant marketing support for distribution channels;

- the absence of methods for the development of organizational and technological documentation (CMP, WEP) and the assessment of the adopted organizational and technological decisions containing recommendations and taking into account the peculiarities of the formation of building flows when synchronizing $\mathrm{AB} C \mathrm{CO}$ and $\mathrm{YT}$ improvement.

\section{Discussion}

The introduction of common principles for the synchronization of organizational and technological decisions in planning urban programs in the housing and utilities sector and in the urban environment relating to $\mathrm{AB} \mathrm{CO}$ and $\mathrm{YT}$ improvement is possible with the active participation of citizens (owners of premises). The practice of attracting people to the implementation of projects provides a positive trend in the satisfaction of the population with comfortable living conditions, as well as ensuring transparency in the spending of financial resources.

When solving this level of problems, it is advisable to use the program-target method, which allows formulating the basic principles of organizational and technical interaction of participants in the process of planning urban programs in the housing and utility services sector and in the urban environment.

Figure 2 presents a matrix of the main activities that the participants in the process of planning urban programs in the housing and utilities sector and the urban environment should perform, depending on the stage of the program and the functions implemented.

\begin{tabular}{|c|c|c|c|c|c|}
\hline \multirow{2}{*}{ Program stage } & \multirow{2}{*}{ Functions } & \multicolumn{2}{|c|}{ Complete overhaul of apartment buildings } & \multicolumn{2}{|c|}{ Yard territory improvement } \\
\hline & & Participants & Events & Participants & Events \\
\hline \multirow[t]{3}{*}{ Concept } & \multirow{3}{*}{$\begin{array}{c}\text { Project } \\
\text { initiation; } \\
\text { concept } \\
\text { development }\end{array}$} & $\begin{array}{c}\text { Federal } \\
\text { government bodies }\end{array}$ & $\begin{array}{l}\text { Regulatory } \\
\text { support }\end{array}$ & $\begin{array}{c}\text { Federal } \\
\text { government bodies }\end{array}$ & $\begin{array}{l}\text { Regulatory support; } \\
\text { determining the amount } \\
\text { of financial subsidies }\end{array}$ \\
\hline & & $\begin{array}{c}\text { Branch-wise } \\
\text { regional government } \\
\text { bodies }\end{array}$ & $\begin{array}{l}\text { Regulatory support; } \\
\text { approval of a long-term } \\
\text { program; }\end{array}$ & $\begin{array}{c}\text { Branch-wise } \\
\text { regional government } \\
\text { bodies }\end{array}$ & Regulatory support \\
\hline & & $\begin{array}{c}\text { Municipal state } \\
\text { government bodies }\end{array}$ & $\begin{array}{c}\text { Initial information } \\
\text { on } \mathrm{AB} \text { wear; } \\
\text { on } \mathrm{CO} \text { previously } \\
\text { held and other criteria }\end{array}$ & $\begin{array}{l}\text { Municipal state } \\
\text { government bodies }\end{array}$ & $\begin{array}{c}\text { YT inventory, } \\
\text { YT examination; } \\
\text { work on involving } \\
\text { owners in } \\
\text { the improvement process }\end{array}$ \\
\hline \multirow[t]{3}{*}{ Planning } & \multirow{3}{*}{$\begin{array}{c}\text { Definition of } \\
\text { the list and } \\
\text { procedure for } \\
\text { the implementation } \\
\text { of processes }\end{array}$} & $\begin{array}{c}\text { Branch-wise } \\
\text { regional government } \\
\text { bodies }\end{array}$ & $\begin{array}{l}\text { Adjustment } \\
\text { of short-term } \\
\text { plans }\end{array}$ & $\begin{array}{l}\text { Branch-wise } \\
\text { regional government } \\
\text { bodies }\end{array}$ & Program approval \\
\hline & & Regional operator & $\begin{array}{l}\text { DED preparation; } \\
\text { tender procedures } \\
\text { preparation }\end{array}$ & $\begin{array}{l}\text { Municipal state } \\
\text { government bodies }\end{array}$ & $\begin{array}{l}\text { DED preparation; } \\
\text { tender procedures } \\
\text { preparation }\end{array}$ \\
\hline & & Owners & $\begin{array}{l}\text { Conducting general } \\
\text { meetings with } \\
\text { approval of work }\end{array}$ & Owners & $\begin{array}{l}\text { Conducting general } \\
\text { meetings with } \\
\text { approval of work }\end{array}$ \\
\hline \multirow[t]{3}{*}{ Implementation } & \multirow[t]{3}{*}{$\begin{array}{l}\text { Work execution, } \\
\text { control, } \\
\text { adjustment }\end{array}$} & $\begin{array}{l}\text { Municipal state } \\
\text { government bodies }\end{array}$ & $\begin{array}{l}\text { Adjustment } \\
\text { of short-term plans }\end{array}$ & $\begin{array}{l}\text { Municipal state } \\
\text { government bodies }\end{array}$ & $\begin{array}{l}\text { Discussion of the project } \\
\text { implementation; } \\
\text { monitoring the progress } \\
\text { of work; acceptance } \\
\text { of work; work financing }\end{array}$ \\
\hline & & Regional operator & $\begin{array}{l}\text { DED preparation; } \\
\text { tender procedures } \\
\text { preparation }\end{array}$ & $\begin{array}{c}\text { Contracting } \\
\text { organizations }\end{array}$ & Works performance \\
\hline & & $\begin{array}{l}\text { Contracting } \\
\text { organizations; } \\
\text { owners }\end{array}$ & $\begin{array}{l}\text { Works performance; } \\
\text { monitoring } \\
\text { the progress of work; } \\
\text { acceptance of work }\end{array}$ & Owners & $\begin{array}{l}\text { Monitoring the progress } \\
\text { of work; acceptance of works }\end{array}$ \\
\hline Completion & Operation & Owners & $\begin{array}{l}\text { Maintenance of } \mathrm{AB} \\
\text { operational features }\end{array}$ & Owners & $\begin{array}{l}\text { Maintenance of YT } \\
\text { operational features; } \\
\text { payment for YT upkeep }\end{array}$ \\
\hline
\end{tabular}

Fig. 2. Matrix of events and results of participants in the planning process of urban programs. 
The basic principle of organizational and technical interaction of participants in the planning of urban programs in the housing and utilities sector and in the urban environment can be formulated as the following rule: between all participants who contribute to the planning of urban programs in the housing and utilities sector and in the urban environment, there should be a clear interaction enshrined in documents being ensure to transfer the information and perform its regular analysis.

Based on this wording, it is possible to formulate the basic principles and proposals for the organizational and technical interaction of the participants in the planning of urban programs in the housing and utilities sector and in the urban environment.

Responsibility, authority and interaction of all participants in the process of synchronization of organizational and technological decisions in planning of urban programs in the housing and utilities sector and in the urban environment that affect the quality of the urban programs planning should be clearly defined in the instructions for each participant, in the provisions for each stage. It is necessary to establish tasks in the field of quality, the extent of responsibility and authority, as well as to determine the circle of persons who should interact in certain cases (stages, planning phases or constantly) when solving assigned tasks. The authority of each participant should allow making decisions within the framework of the tasks assigned.

The responsibility, authority and interaction of each participant are correctly and fully determined only in the process of urban programs planning, when each function, task, procedure are assigned to the person responsible for their implementation and the order of interaction is determined. For a visual representation of the responsibility and interaction of the participants in the process of planning urban programs in the housing and utility services sector and in the urban environment, it is necessary to develop responsibility matrices and other graphical representations.

The organizational and technical interaction, as well as the management of interaction between the participants in the planning of urban programs in the housing and utility services sector and in the urban environment, should be implemented in the way to ensure effective communication between them and a clear distribution of responsibility in which all the required information is documented, transmitted and periodically analyzed:

- The order of interaction between participants in the planning of urban programs at various stages is established in the documents, including upon approval of the annual program and technological charts and instructions;

- The coordination of the work of units and contractors and the organization of their interaction should be ensured depending on the regional specifics and the existing structure of state authorities in the Russian Federation subject: either by a separate executive body, or by a structure subordinate to the branch state authority, or directly by the head of the Russian Federation subject;

- The content and sequence of stages of the planning processes of urban programs in the housing and utilities sector and in the urban environment;

- The specific distribution of duties and powers of participants in the planning at various stages of the program;

- The application of specific documented procedures and available technological instructions on the procedure for carrying out works for all participants in the planning process;

- and other elements of interaction of participants in the planning within the framework of existing legal acts ensuring the implementation of the goals set by the program.

The paper proposes a procedure for establishing the organizational and technical interaction of participants in the process of planning urban programs in the housing and utility services sector and in the urban environment, which includes: 
1. Identification of specific legal entities (state authorities, specialized companies, etc.) involved in the planning of urban programs in the housing and utilities sector and in the urban environment, including subcontracting organizations;

2. Establishment of the main channels for the exchange of information and responsibility for its content (compilation of a list of requirements for the type and amount of data transferred).

Based on the above principles and proposed procedures, in the framework of this study, an algorithm for planning urban programs in the housing and utilities sector and in the urban environment is presented in the form of a technological layout that demonstrates the organizational and technical interaction of the participants in the planning of urban programs.

This layout of the organizational and technical interaction of the participants in the planning of urban programs allows:

- identification of all units involved in the planning of a particular facility;

- establishing a list of all interactions between units (terms for issuing and receiving assignments, linking assignments between subcontractors, allocation of estimated cost between units) and a list of control and preventive actions on the part of state authorities, for all those involved in planning urban programs in the housing and utilities sector and in the urban environment.

The main criteria for the responsibility of participants in the planning of urban programs in the exchange of information are:

- Compliance with the deadlines for the assignment of tasks to subcontractors established by the facility schedule;

- Exclusion of critical situations leading to the redistribution of internal resources, which reduces the quality of work, or to a change in the general periods of time.

In order to eliminate the occurrence of critical situations leading to the redistribution of internal resources, reduction of the quality of work or change in the general periods of time, the main risks were identified and measures were taken to reduce the likelihood of adverse effects.

When implementing urban programs in the housing and utilities sector and in the urban environment, risks may arise that affect the final results of the implementation of programs, which include:

- budgetary risks associated with the deficit of regional and local budgets and the possibility of default of obligations on co-financing of program activities;

- social risks associated with low social activity of the population, absence of mass culture of participation in complete overhauls, yards landscaping, etc.;

- managerial (internal) risks associated with ineffective management of the implementation of urban programs, low quality of interagency cooperation, inadequate control over the implementation of the program in the housing and utilities sector and in the urban environment, etc.;

- other risks that may impede the implementation of programs in the housing and utilities sector and in the urban environment.

The following measures are provided to prevent risks, reduce the likelihood of adverse effects and ensure the uninterrupted implementation of urban programs in the housing and utilities sector and in the urban environment:

- implementation of a set of activities to involve citizens and organizations in the planning urban programs in the housing and utilities sector and in the urban environment, involvement in the implementation of measures for $\mathrm{AB}$ CO and YT improvement;

- implementation of public control over the progress of $\mathrm{AB} \mathrm{CO}$ and the YT improvement; 
- monitoring the progress of $\mathrm{AB} \mathrm{CO}$ and $\mathrm{YT}$ improvement, including the implementation of specific activities under the urban programs in the housing and utilities sector and in the urban environment.

\section{Conclusions}

For the task associated with the implementation of the unified principles of synchronizing organizational and technological solutions when planning urban programs in the housing and utilities sector and in the urban environment related to $\mathrm{AB} \mathrm{CO}$ and YT improvement, the following results were obtained:

When synchronizing the $\mathrm{AB} \mathrm{CO}$ and $\mathrm{YT}$ improvement works, there can be many different options for the sequence of types of works for AB CO and YT improvement, from which it is necessary to choose the most rational one.

The aforesaid shows that all significant changes in the duration of the scope of works for $\mathrm{AB} \mathrm{CO}$ and $\mathrm{YT}$ improvement are quite fully evaluated by a system of parameters and coefficients, with the help of which features of not only rhythmically and differently performed types of work can be expressed, but also the ones of their combination under different conditions of production organization.

Proposals on the organizational and technical interaction of the participants in the planning of urban programs in the housing and utility services sector and in urban environment were formed, including the ones for all levels of government authorities;

The requirements to the organizational and technical interaction of the participants in the planning of urban programs in the housing and utilities sector and in the urban environment were determined, including those involving not only participants in the production process, but also owners;

An algorithm for planning urban programs in the housing and utilities sector and in the urban environment was developed, which is presented in the form of a technological layout that clearly demonstrates the organizational and technical interaction of the planning process participants.

\section{References}

1. E.O. Mirgorodskaya, I.V. Novoselova, V.Y. Steiner, Organizational and Managerial Failures in the Development of the Housing Industry in Russia. Mat.

Scie. $\quad$ For., $\quad$ 931, 1160-1164

https://doi.org/10.4028/www.scientific.net/MSF.931.1160

2. E.O. Mirgorodskaya, S.A. Sukhinin, Housing Construction and Economic Dynamics in Largest Cities of Russia. Mat. Scie. For., 931, 1148-1153 (2018) https://doi.org/10.4028/www.scientific.net/MSF.931.1148

3. S.V. Domnina, E.V. Savoskina, N.V. Shekhova, On Innovative Decisions in the Investment-construction Cycle. Proc. Eng., 153, 741-746 (2016) https://doi.org/10.1016/j.proeng.2016.08.236

4. S. Sheina, A. Fedorovskaya, Ecological aspects in assessment of acoustic pollution at the territory of Rostov-on-Don. MATEC Web of Conf., 106 (2017) https://doi.org/10.1051/matecconf/201710607010

5. M. Péti, A territorial understanding of sustainability in public development. Envir. Imp. Ass. Rev., 32 (1), 61-73 (2012) https://doi.org/10.1016/j.eiar.2011.03.004

6. A. Abdulai, V. Owusu, R. Goet, Land tenure differences and investment in land improvement measures: Theoretical and empirical analyses. J. of Develop. Ec., 96, 66-78 (2011) https://doi.org/10.1016/j.jdeveco.2010.08.002 
7. S. Sheina, D. Wingand, R. Roman, L. Teryukova, Management of Territory Development Based on an Integrated Assessment. Eur. Scie. Rev., 11-12, pp. 214219 (2015)

8. S. Sheina, L. Girya, A. Lapina, Use of ground surface deformations monitoring data for control of housing facilities health. MATEC Web of Conf., 106, 02024 (2017) https://doi.org/10.1051/matecconf/201710602024

9. A. Larionov, Yu. Larionova, L. Selivanova, Regional Peculiarities of Energy Saving Development During the Exploitation of Housing and Underground Housing and Utility Sector Objects, Proc. Eng., 165, pp. 1229-1232 (2016) https://doi.org/10.1016/j.proeng.2016.11.844

10. T. Morozova, N. Bokovaya, L. Khazieva, System Approach to the Surveying of Real Estate in Scheduling of Repair and Construction Works. Proc. Eng., 117, 1090-1096 (2015) https://doi.org/10.1016/j.proeng.2015.08.241

11. S. Sheina, A. Fedorovskaya, K. Yudina, Smart City: Comfortable Living Environment. IOP Conf. Ser.: Mat. Scie. and Eng., 463, 032095 (2018) https://doi.org/10.1088/1757-899X/463/3/032095

12. S.G. Abramyan, Environmental Compliance During Construction. Proc. Eng., 150, 2146-2149 (2016) https://doi.org/10.1016/j.proeng.2016.07.255

13. I.Y. Zilberova, Methods and Models of Multi-Criteria Evaluation of Design Solutions for Installation of Special Constructions. Used for Prob.-Solv. of Judic. Constr.and Tech. Exp., Mat. Scie. For., 931, pp. 834-839 (2018) https://doi.org/10.4028/www.scientific.net/MSF.931.834

14. P. Nowotarski, J. Pasławski, Ł. Pluciński, Scientific association knowledge improvement activities in Construction Technology Management field. Proc. Eng., 208, 106-113 (2017) https://doi.org/10.1016/j.proeng.2017.11.027

15. A. Abdi, S. Taghipour, Sustainable asset management: A repair-replacement decision model considering environmental impacts, maintenance quality, and risk. Comp. \& Indust. Eng., 136, pp. 117-134 (2019) https://doi.org/10.1016/j.cie.2019.07.021

16. T.A. Shindina, Organization of Interaction between the Participants in Modern Construction. Proc. Eng., 150, pp. 2113-2118 (2016) https://doi.org/10.1016/j.proeng.2016.07.249 